\title{
Sciendo
}

\section{Internal Audit Risk Assessment in the Function of Fraud Detection}

\author{
Lejla Demirović \\ School of Economics and Business, University of Sarajevo \\ lejla.demirovic@efsa.unsa.ba \\ Ševala Isaković-Kaplan \\ School of Economics and Business, University of Sarajevo \\ sevala.isakovic-kaplan@efsa.unsa.ba
}

\begin{abstract}
Mahir Proho
AS Holding, Internal audit mahirproho@gmail.com

Abstract

We are witnessing an increasing frequency of illegal actions and fraud in the business of legal entities, which directly reflects on the quality of information presented in financial statements. Internal audit does not primarily deal with the audit of financial statements, but through verifying the application of accounting policies and procedures it helps to gain reasonable assurance that the financial statements are reliable and that they are presented fairly. The role of internal audit in the fraud detection process is reflected in the fraud risk assessment in the internal audit planning process, and through performing work engagements to detecting them. In this paper, we will present risk assessment techniques, which the internal auditor can apply in quantitative and qualitative assessment of fraud risk, and in identifying priority areas/audit processes. The aim of this paper is to point out the importance of the role of internal audit, through the application of techniques, tools and prescribed responsibilities for risk assessment, in the process of detecting fraud in companies that cause incalculable damage on a daily basis.
\end{abstract}

Key words: Internal Audit, Risk Assessment, Planning, Auditing, Fraud Detection

Paper type: Non-research article

Received: April 22, 2021

Accepted: May 30, 2021

Citation: Demirović, L., Isaković-Kaplan, Š., Proho, M. (2021), "Internal Audit Risk Assessment in the Function of Fraud Detection", Journal of Forensic Accounting Profession, Vol. 1, No. 1, pp. 35-49.

DOI: https://doi.org/10.2478/jfap-2021-0003 


\section{Introduction}

Internal audit is an independent activity whose role is to provide independent expert opinion, advices and recommendations for business improvement, helps the legal entity (company/institution) in realization the set goals by applying a systematic approach to assessing the adequacy of established risk management processes, internal controls, business management, application of prescribed procedures, etc. Although risk assessment has a wide meaning and scope in the work of internal audit, however, it can be pointed out that the greatest contribution to risk assessment in the work of internal auditors is in the process of identifying priority (risk) areas/business processes, that is, long-term planning of internal audit work, all for the purpose of detecting fraud and irregularities, in order to reduce the risk of fraud to the lowest possible level. Risk assessment techniques are being improved daily by internal auditors, they are trained on a daily basis, so that the company's internal management can give advice on how to manage risks most effectively.

Internal audit is performed by persons who have the expertise of internal auditors. Internal auditors perform audits of the area/process of the company in which they are employed, they are hired by an individual company, the conditions for performing the audit may be regulated by regulations (legal regulations, international standards and internal regulations). Internal auditors mainly deal with the audit of compliance and operations, and less with the audit of financial statements.

The research area of this paper is the activities of internal audit on risk assessment in the function of prevention and detection of fraud. The contribution of the work is reflected in the presentation of the risk assessment approach that can be used by internal auditors for the purposes of active risk management in the organization. An adequate approach to risk assessment in audit planning enables the prioritization of risk areas (including fraud risks) and strengthens anti-fraud capacities.

The main goal of this paper is to point out the importance of the role of internal audit in fraud prevention and detection through a comprehensive approach to risk assessment. In addition, one of the goals of the paper is to provide internal auditors a kind of guide to assist in risk assessment and prioritization of activities. Furthermore, the adequate application of qualitative and quantitative assessment techniques ensures that internal audit contributes to the fight against fraud. The structure of the paper is as follows: first, the internal audit activities on risk area identification will be presented, then the role of internal audit in detecting fraud will be analyzed, and finally the methods for assessing internal audit risk will 
be presented. Lastly, concluding remarks are considered, including limitations and recommendations for further.

\section{Identification of internal audit risk areas}

All activities of human life, including the life of an organization, are subject to risks. In the literature, we encounter many definitions of risk, depending on the aspect of definition. However, all definitions have in common that the risks are represent future uncertainties and they carry a loss with them.

Likewise, there are many classifications and risk divisions. Here we will highlight the most important ones, related to the management process in the company. According to Keitsch (2000, p. 11), risks can be classified into three categories, of which the first category includes force majeure risks, the second category political and economic risks, and the third category of business risks (company risks, business risks in the narrow sense, financial risks). Also, the risks in the company can be divided as: inancial and non-financial, static and dynamic, pure and speculative, external and internal, etc (Osmanagić-Bedenik, 2003, p.68). A very commonly used classification is also on strategic risks, operational risks, financial risks and gambling risks (Walker et al., 2002, p. 3).

According to today's understanding of internal audit, internal audit consulting activities should ensure an adequate risk management process. In the definition of the Institute of Internal Auditors, this key activity is embedded through the need for internal audit to ensure ,a systematic, disciplined approach to assessing and improving the effectiveness of risk management." The role of internal audit to support the company includes "activities to identify and assess significant risk exposures, and contributing to the improvement of risk management and control systems." (The IIA Research Foundation, 2007, p. 14).

The risk management process includes four phases, which are risk identification, quantitative and qualitative assessment of documented risks, determining priorities among the identified risks, as well as defining risk treatment strategies, and monitoring risks, ie the process of their management (Moeller, 2007, p. 22). Risk identification in all defined areas/processes of internal audit includes the procedures is presented in Figure 1. 
Figure 1: Risk identification procedures
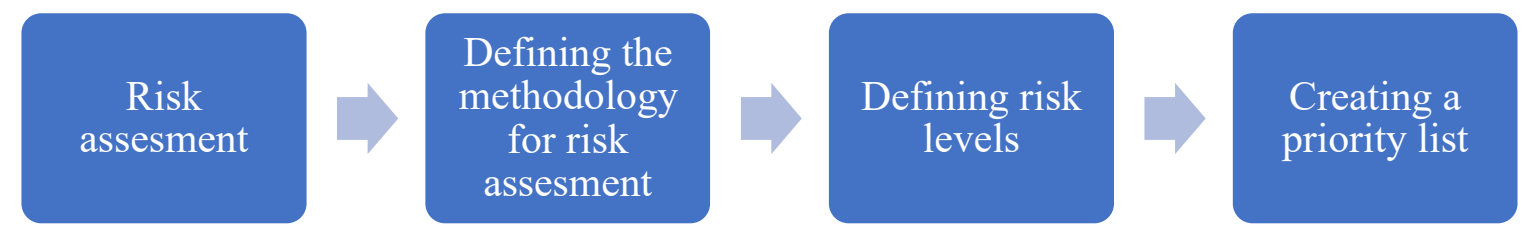

Source: Author's processing

The first step includes the process of determining risk through business areas/processes, events that may occur and to influence the realization of defined goals and priorities and the realization of business areas/processes. Risk assessment includes the phase of the entire risk management process, identification and analysis of relevant risks that affect the achievement of the company's goals, in order to successfully manage the defined risks.

In order to successfully identify areas of risk, internal auditors start from the following internal sources of information:

- Interview with employees (priority: interview with management) - the goal is to gather information about problems and difficulties that are present in the business;

- Analyze risks (risk matrices) - if the same can be implemented;

- Analyze internal audit work plans (strategic, annual, operational) and reports on their implementation;

- Analyze a set of financial statements (balance sheet, income statement, cash flow statement, statement of changes in equity and notes to the financial statements) - the aim of this analysis is to identify trends and objectively assess risk. It is considered desirable to look at sets of financial statements for several years, in order to determine trends;

- Analyze internal and external audit reports, and reports of other competent authorities (authorities, tax authorities, supervisors, etc.);

- Consider other sources of information.

Once the risks have been identified, they need to be assessed in order to rank them, set priorities and receive information for decision-making on those risks to which due attention should be paid. Only key (main) risks will be taken into account in the risk assessment. The procedure (methodology) that internal audit will use to assess risk usually depends on the choice of management of the legal entity. 
The risk assessment is essentially based on a subjective assessment of the same by the chief internal auditor, with the use of different techniques to make the analysis systematic and to some extent more objective. The use of certain methods (techniques) for risk assessment is necessary in order for internal auditors to be able to prove the assessment, in terms of audit priority and frequency, which will assist the auditor in identifying areas that carry a significant level of risk.

The internal auditor in the risk assessment process is obliged to define risk levels. Risk levels can be defined through quantitative and qualitative parameters. An example for defining the level of internal audit risk is through grades 1 to 3, which are assigned meanings:

- Risk mark "1" - low level of risk (represents the risk of the lowest possible level);

- Risk mark "2" - medium level of risk (represents medium level risk); and

- Risk mark "3" - high level of risk (represents the risk of the highest level).

The subject risk assessment ensures the coverage of all key areas/business processes of the legal entity. If there are areas/processes of audit that are similar in their business or interconnected, they can be merged and revised through a single audit.

\section{The role of internal audit in detecting fraud}

Some research has confirmed that the existence of internal audit also adds value through reducing the risk of fraud (Carey et al. 2000; Goodwin and Kent 2004; Carcello et al. 2005). Wallace and Kreutzfeldt (1991) found that in organizations where internal audit was established, less error was detected by external audit. Nestor (2004) concluded that internal audit is a powerful management tool to protect organizations from internal fraud. In addition to the role of internal audit in corporate governance mechanisms, its role in mitigating the risk of fraud is growing (Beasley et al., 2000; Coram et al., 2008).

International Standards on Auditing 240 - The Auditor's Responsibility to Consider Fraud in the Audit of Financial Statements (ISA 240), defines fraud as the intentional act of one or more persons within management, those charged with governance, employees, or third parties, involving the use of deception to obtain an unjust or illegal advantage. From the above definition of fraud and called ISA 240 we can see that the same standard prescribes the responsibilities of auditors in the audit of financial statements, however, although the primary task of internal audit is not to audit the financial statements, however, internal auditors supervise the financial statements through checks on the application of prescribed policies and procedures, contribute to providing reasonable assurance about the reliability of the financial 
statements and the fair presentation of the financial statements. Although ISA 240 does not directly link the internal auditor to fraud detection responsibilities, International Standards for the Professional Practice of Internal Auditing 1210 - Proficiency, through section 1210 A2 stipulates that the Internal auditors must have sufficient knowledge to evaluate the risk of fraud and how the company manages that risk, but the internal auditor is not expected to have the same level of expertise in fraud as a person whose primary responsibility is detecting and investigating fraud. Therefore, the external audit is limited to the requirements of ISA 240, ie it focuses on fraud in the financial statements. In contrast, internal auditors face a wider range of fraud risks, including risks of misappropriation of assets (Chadwick, 2000).

The contribution of internal audit in terms of detecting fraud is reflected, both in detecting fraud and in preventing its occurrence, fraud risk assessment in audits and events. Through fraud risk assessment, the internal auditor assesses the presence and probability of its occurrence and makes recommendations on how it should be managed through risk assessment and audit planning.

Due to the importance of internal audit in fraud prevention and detection, and on the other hand its status in the organization, the key problem is independence, which can jeopardize the realization of the internal audit mission. Therefore, the imperative facing internal auditors is their independence in all activities, including an impartial risk assessment of all forms of fraud (King, 2000; Demski, 2003; Balkaran, 2007; Salierno, 2007; Kaplan \& Schultz, 2007).

When an internal auditor audits a particular area/process in your company and discovers that there is a particular fraud or suspects that the fraud may exist, in the further audit process, the focus should be on the audit of the internal control system areas/processes for which there is a suspicion of fraud or that fraud has already been detected. The aim of the audit of the internal control system is to determine whether the internal control system exists and performs its function in an adequate manner, ie that internal controls have been complied with, ie whether the omissions in the functioning of the internal control system led to the occurrence of fraud. From this we can see that the internal auditor focuses on internal controls as the first procedure in case a fraud is detected or there is a suspicion that it could arise.

Further, after the internal auditor has determined the cause of the fraud, he looks more broadly, by asking the question: „Which areas/processes in the company's business are exposed to the possibility of the same or similar frauds? ". If the internal auditor considers that there are areas/business processes in the company where a similar fraud could occur, the verification procedure is carried out as follows: 
- Check whether these areas/business processes in companies are planned by the internal audit work plan (strategic, annual, operational plan);

- If the same areas/processes are not planned in the work plan, they direct the further procedure to check whether the audit of the area/process, for which there is a suspicion of fraud, is cost-effective in terms of audit resources (financial, time and human) or whether there is a justification for initiating an extraordinary audit;

- That internal auditors will check how the prescribed audit procedures can improve the detection of fraud, noting that there are no single audit procedures (legal and by-laws) that could be applied in the fraud detection process.

In the event that the internal auditor detects fraud in his company, he should act in such a way that gives recommendations to the company's management in order to eliminate the identified shortcomings by internal audit and if possible, develop a program (methodology) for fraud detection (risk matrix development). The procedures for the internal auditor to refrain from detecting fraud are:

- Do not make a proposal to the management of the legal entity/institution to sanction the perpetrator of fraud (e.g. not make a proposal for disciplinary measures, fines, disincentives, etc.);

- Do not place information in the public, ie. act in a way that the management of the company is informed, and strive to ensure that in the initial phase of detecting fraud, information about the fraud is of an internal nature;

- Do not submit a report to the competent authorities (court, prosecutor's office) for sanctioning fraud.

The above confirms that the internal auditor in case of detection of fraud should limit his role to advisory, and not the role of the responsible person in the company to resolve fraud.

\section{Methods (techniques) of internal audit risk assessment}

Although the primary task of internal audit is to audit business areas/processes, internal auditors make daily increasing efforts to learn and master techniques related to risk assessment of the area/process of the company's business, and informing the company's management about the opportunities that the same techniques provide in order to successfully overcome the risks to which the company's business is exposed. In this paper, the process of risk assessment by the internal auditor will be presented through the application of risk 
assessment techniques using a risk matrix and risk assessment technique using a questionnaire.

\subsection{Risk assessment technique using a risk matrix}

This method starts from the position that when assessing the probability of occurrence and the amount of risk, it is necessary to consider (define) risk factors. Risk factors are criteria used to identify the relative importance and probability that conditions and/or events will occur that may adversely affect the business of an enterprise. The factors (criteria) that the company will use in risk assessment and ranking the areas/business processes for the priority of the audit, they vary from company to company and depend on the choice of business entity. The method of risk assessment using defined factors can be observed through three phases, as presented in Figure 2.

Figure 2: Phases of risk assessment

\section{Defining factors}

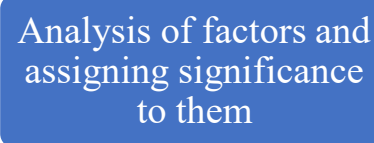

Analysis of factors and to them

Source: Author's processing
Risk calculation using a risk matrix 
The technique of risk assessment using the significance factor will be presented in the Table 1.

Table 1: Risk assessment technique using a significance factor

\begin{tabular}{|c|c|c|c|c|}
\hline \multicolumn{5}{|c|}{ Stages of the risk assessment process } \\
\hline Stage 1 & & Stage 2 & & \multirow{2}{*}{$\begin{array}{c}\text { Stage } 3 \\
\text { Risk } \\
\text { matrix } \\
\end{array}$} \\
\hline $\begin{array}{l}\text { Defining } \\
\text { risk factors }\end{array}$ & \multicolumn{3}{|c|}{ Risk factor analysis and assignment of significance } & \\
\hline \multirow{4}{*}{$\begin{array}{c}\text { Job } \\
\text { size/transacti } \\
\text { on volume }\end{array}$} & $\begin{array}{l}\text { Risk } \\
\text { level }\end{array}$ & $\begin{array}{l}\text { Percentage volume of participation in the } \\
\text { balance sheet }\end{array}$ & $\begin{array}{l}\text { Significance } \\
\text { factor }\end{array}$ & $\stackrel{\infty}{\Xi} \stackrel{0}{\Xi}$ \\
\hline & 1 & $0-2,5 \%$ & \multirow{3}{*}{ (x) } & $\frac{0}{0} \quad \stackrel{0}{0} \quad \bar{\Xi}$ \\
\hline & 2 & $2,5-5 \%$ & & 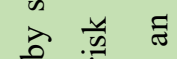 \\
\hline & 3 & $>5 \%$ & & $\vec{z}=\cong$ \\
\hline \multirow{4}{*}{$\begin{array}{l}\text { Quality of } \\
\text { internal } \\
\text { control } \\
\text { system }\end{array}$} & $\begin{array}{l}\text { Risk } \\
\text { level }\end{array}$ & Description of internal controls & $\begin{array}{c}\text { Significance } \\
\text { factor }\end{array}$ & 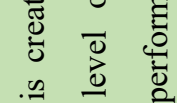 \\
\hline & 1 & Good/Satisfactory internal controls & \multirow{3}{*}{ 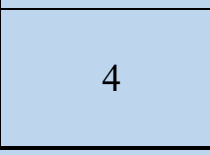 } & $\cong \approx$ \\
\hline & 2 & Acceptable/Minimum internal controls & & $=3$ \\
\hline & 3 & Unsatisfactory internal controls & & 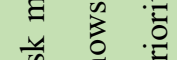 \\
\hline \multirow{4}{*}{$\begin{array}{l}\text { Time elapsed } \\
\text { since previous } \\
\text { revision }\end{array}$} & $\begin{array}{l}\text { Risk } \\
\text { level }\end{array}$ & Time elapsed since previous revision & $\begin{array}{c}\text { Significance } \\
\text { factor }\end{array}$ & 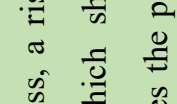 \\
\hline & 1 & From six to twelve months & \multirow[t]{3}{*}{ 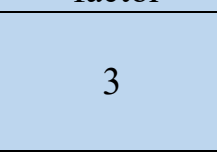 } & $\stackrel{\circlearrowright}{\oplus} \bar{\Xi}$ \\
\hline & 2 & Twelve to twenty-four months & & 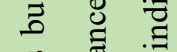 \\
\hline & 3 & Twenty-four to thirty-six months or more & & $\sum \stackrel{0}{2}=$ \\
\hline \multirow{4}{*}{$\begin{array}{c}\text { The result of } \\
\text { the last } \\
\text { revision }\end{array}$} & $\begin{array}{l}\text { Risk } \\
\text { level }\end{array}$ & Description of risk audit & $\begin{array}{l}\text { Significance } \\
\text { factor }\end{array}$ & 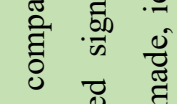 \\
\hline & 1 & Low risk & \multirow{3}{*}{2} & $\stackrel{0}{\rightleftarrows}$. \\
\hline & 2 & Medium risk & & 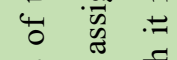 \\
\hline & 3 & High risk & & 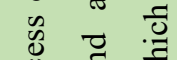 \\
\hline \multirow{4}{*}{$\begin{array}{l}\text { Impact of } \\
\text { regulation }\end{array}$} & $\begin{array}{l}\text { Risk } \\
\text { level }\end{array}$ & Level of regulation & $\begin{array}{c}\text { Significance } \\
\text { factor }\end{array}$ & 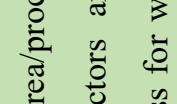 \\
\hline & 1 & $\begin{array}{l}\text { There are no up to a few prescribed } \\
\text { requirements }\end{array}$ & \multirow{3}{*}{1} & 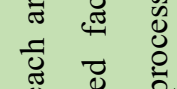 \\
\hline & 2 & Moderate level of prescribed requirements & & ङ \\
\hline & 3 & High level of prescribed requirements & & \\
\hline
\end{tabular}

Source: Author's processing

The number of risk factors is arbitrary and depends on the decision of the company. Each defined risk factor needs to be assigned to each individual risk factor. We have defined five key factors, and each factor must be accompanied by a significance factor in the range of 1 to 5 , where the significance factor assigned range 1 represents the least impact, while the factor assigned range 5 represents the greatest impact on the areas/processes of the enterprise.

A risk matrix needs to be created for each area/process of the companies that bear the risk, using defined characteristic risk factors related to the area/process for which the risk is assessed. The data used in the risk calculation (risk matrix) are: risks factors and levels of 
their significance; risk assessment and their rank; cumulative risk exposure and audit priorities. The risk calculation should include only those risk factors that have a significant impact on the area/process whose risk is being assessed. It is not precisely defined how many risks factors the risk calculation should contain, but three to five risk factors are considered sufficient. The choice of risk factors and their number is determined by the internal auditor on the basis of subjective assessments and previously acquired experience in the same or similar audits. Using defined risk factors and assigned significance levels, in the Table 2, we will present the risk assessment procedure using a risk matrix.

Table 2: Risk matrix

\begin{tabular}{|c|c|c|c|c|c|}
\hline \multicolumn{6}{|c|}{ Risk matrix for: (specify area/business process) } \\
\hline Risk factors & $\begin{array}{l}\text { Significance } \\
\qquad(1-5)\end{array}$ & $\begin{array}{c}\text { Risk } \\
\text { assessment } \\
(1-3)\end{array}$ & $\begin{array}{l}\text { Risk } \\
\text { rank }\end{array}$ & $\begin{array}{c}\text { The result } \\
\text { risk } \\
\text { assessments }\end{array}$ & $\begin{array}{l}\text { Priority and } \\
\text { explanation }\end{array}$ \\
\hline 1 & 2 & 3 & 4 & $5(2 \times 3)$ & 6 \\
\hline $\begin{array}{l}\text { Job size/transaction } \\
\text { volume }\end{array}$ & 5 & 2 & Medium & 10 & \multirow{7}{*}{$\begin{array}{l}\text { The average risk } \\
\text { assessment is } 2 . \\
\text { Provide information } \\
\text { on audit priority. } \\
\text { State the } \\
\text { assumption of the } \\
\text { impact of risk on } \\
\text { the company's } \\
\text { operations } \\
\text { (minimal, medium, } \\
\text { and high). }\end{array}$} \\
\hline $\begin{array}{l}\text { Quality of internal } \\
\text { control system }\end{array}$ & 4 & 2 & Medium & 8 & \\
\hline $\begin{array}{l}\text { Time elapsed since } \\
\text { previous revision }\end{array}$ & 3 & 1 & Low & 3 & \\
\hline $\begin{array}{l}\text { The result of the last } \\
\text { revision }\end{array}$ & 2 & 2 & Medium & 4 & \\
\hline Impact of regulation & 1 & 2 & Medium & 2 & \\
\hline Total & 5 & 9 & - & 27 & \\
\hline \multicolumn{5}{|c|}{$\begin{array}{l}\text { TOTAL: Average risk rating: } 1.80^{*} \\
* \text { Sum of risk assessments/Number of applied risk factors }\end{array}$} & \\
\hline
\end{tabular}

Source: Author's processing

Legend:

- Risk rank *: high, medium, low

- Priority **: high, medium, low

Through Table 2 we have present the process of creating a risk matrix for individual areas/processes of the company. After creating individual matrices, it is necessary to make a summary risk matrix, which will be a summary of all risk factors associated with this area, the value significance of the risk factor, the risk rating given in the range 1 to 3 , the risk rank (high, medium or low) and the priority for the performed audit. The assessment of risk and 
risk rank, for each individual factor, is assigned by the internal auditor according to a subjective assessment, and for each assigned assessment and risk rank, an explanation must be given. By compiling risk matrices (individual and collective) by areas that were subject to assessment, the list of priorities for internal audit is drawn up, ie the development of a strategic, annual and operational work plan for internal audit and the performance of individual audits based on risk.

The risk priority can be defined as high, medium/acceptable and low, and the length of the observed period is three years, in accordance with the strategic plan. Based on the defined grades and parameters, the internal auditor compiles a priority matrix, and then a list of audit priorities. The list of priorities should contain at least the following information: ordinal number; risk-bearing area/pre-process; risk assessment (1-3); risk rank; priority for conducting the audit; type of internal audit.

\subsection{Risk assessment technique using a questionnaire}

One of the techniques by which the internal auditor can identify risk is the technique of applying the survey questionnaire. The technique of risk assessment through a questionnaire is carried out at the level of organizational units of the company, which means that each organizational part fills out a survey questionnaire and submits it to the internal auditor. The aim of the survey questionnaire is to determine the area/process/area that will be subject to audit. The survey questionnaire evaluates risk factors and assesses the types of risks for each factor. For each selected risk factor, it is necessary to determine the significance and degree of risk. The technique of risk assessment using the survey questionnaire will be presented in the Table 
Table 3. Survey questionnaire for risk assessment at the level of organizational unit

\begin{tabular}{|c|c|c|c|c|c|c|c|c|c|c|c|c|}
\hline \multicolumn{11}{|l|}{ RISK RANGE } & Min & Max \\
\hline \multicolumn{11}{|l|}{ High risk } & 2.34 & 3.00 \\
\hline \multicolumn{11}{|l|}{ Medium risk } & 1.67 & 2.33 \\
\hline \multicolumn{11}{|l|}{ Low risk } & 1.00 & 1.66 \\
\hline \multirow{4}{*}{$\begin{array}{c}\text { Organizational } \\
\text { unit }\end{array}$} & \multicolumn{10}{|c|}{ Risk factors } & & \\
\hline & \multirow{2}{*}{\multicolumn{2}{|c|}{$\begin{array}{c}\text { Financial } \\
\text { significance } \\
0,40\end{array}$}} & \multicolumn{2}{|c|}{ Control environment } & \multirow{2}{*}{\multicolumn{2}{|c|}{$\begin{array}{c}\text { Scope and intensity of } \\
\text { change } \\
0.05\end{array}$}} & \multicolumn{2}{|c|}{ Trust in leadership } & \multicolumn{2}{|c|}{ Risk Fraud } & \multirow{3}{*}{$\begin{array}{l}\text { Total } \\
\text { risk } \\
\text { index }\end{array}$} & \multirow{3}{*}{ Priorities } \\
\hline & & & \multicolumn{2}{|c|}{0,30} & & & \multicolumn{2}{|c|}{0,05} & \multicolumn{2}{|c|}{0,20} & & \\
\hline & \multicolumn{2}{|c|}{ Scoring 0,40} & Scoring & Total & Scoring & Total & Scoring & Total & Scoring & Total & & \\
\hline \multirow{3}{*}{$\begin{array}{l}\text { Risk factor } \\
\text { scoring }\end{array}$} & \multicolumn{2}{|c|}{$\begin{array}{l}1 \text { - } \\
\text { revenues/expenses } \\
\text { less than } 100,000 \\
\text { KM per year }\end{array}$} & \multicolumn{2}{|c|}{$\begin{array}{l}1 \text { - good control } \\
\text { environment }\end{array}$} & \multicolumn{2}{|c|}{$\begin{array}{l}1 \text { - there is no } \\
\text { pronounced turnover } \\
\text { of employees/business } \\
\text { processes do not } \\
\text { change often }\end{array}$} & \multicolumn{2}{|c|}{$\begin{array}{l}1 \text { - managers with } \\
\text { high competencies }\end{array}$} & \multicolumn{2}{|c|}{$\begin{array}{l}1 \text { - fraud has not } \\
\text { occurred in the past } \\
\text { three years/the } \\
\text { organizational unit is } \\
\text { not subject to fraud }\end{array}$} & & \\
\hline & \multicolumn{2}{|c|}{$\begin{array}{l}2 \text { - } \\
\text { revenues/expenses } \\
\text { of } 100,000-500,000 \\
\text { KM per year }\end{array}$} & \multicolumn{2}{|c|}{$\begin{array}{l}2 \text { - satisfactory } \\
\text { control environment }\end{array}$} & \multicolumn{2}{|c|}{$\begin{array}{l}2 \text { - there is a moderate } \\
\text { fluctuation of } \\
\text { employees/processes } \\
\text { change occasionally }\end{array}$} & \multicolumn{2}{|c|}{$\begin{array}{l}2 \text { - managers with } \\
\text { intermediate } \\
\text { competencies }\end{array}$} & \multicolumn{2}{|c|}{$\begin{array}{l}2 \text { - fraud has } \\
\text { occurred in the past } \\
\text { three years/the } \\
\text { organizational unit is } \\
\text { not significantly } \\
\text { susceptible to fraud }\end{array}$} & & \\
\hline & \multicolumn{2}{|c|}{$\begin{array}{l}3 \text { - } \\
\text { revenues/expenses } \\
\text { over } 500,000 \mathrm{KM} \text { per } \\
\text { year }\end{array}$} & \multicolumn{2}{|c|}{$\begin{array}{l}3 \text { - unsatisfactory } \\
\text { control environment }\end{array}$} & \multicolumn{2}{|c|}{$\begin{array}{l}3 \text { - significant } \\
\text { employee turnover is } \\
\text { expressed/processes } \\
\text { change frequently }\end{array}$} & \multicolumn{2}{|c|}{$\begin{array}{l}3 \text { - managers with } \\
\text { low competencies }\end{array}$} & \multicolumn{2}{|c|}{$\begin{array}{l}3 \text { - more than one } \\
\text { fraud has occurred in } \\
\text { the past three } \\
\text { years/the } \\
\text { organizational unit is } \\
\text { subject to fraud }\end{array}$} & & \\
\hline
\end{tabular}

Source: Author's processing, according to the instructions of the Federal Ministry of Finance BiH 
The internal auditor defines the number of factors, and the heads of organizational units assign weights in accordance with the assessment of the significance of individual risk factors. Based on the descriptive criteria, the risk factors are scored with grades from 1 to 3 , which ultimately gives the overall risk index and priority category.

\section{Conclusion}

Internal audit through the performance of its primary tasks (compliance audits and performance audits): performing individual audits of business areas/processes, making recommendations, checking the functioning of the internal control system, planning the work of the audit, makes a great contribution to risk management for the management of which the management of the company is directly responsible. The purpose of this paper was to expand theoretical knowledge about the role of internal audit in risk assessment as a powerful tool for fraud prevention and detection.

The fact is that there are no legal regulations in $\mathrm{BiH}$ that require internal audit as a mandatory segment in the operations of all business entities (except for the public and financial sector for which there is a legal obligation to have internal audit), which is one of factors of slow development and strengthening the role of internal audit. Therefore, this paper also contributes to the practical work of internal auditors, who can use the presented techniques in risk assessment in order to respond as readily as possible to the risks of fraud in organizations.

One of the limitations is the fact that each general model should be adapted to the specifics of one organization, as is the case with this. Furthermore, successful risk assessment depends on the competencies of internal auditors, but also the cooperation of the head of the organization, where the lack of cooperation can lead this model in the wrong direction, prioritizing areas that are not really priority, and bypassing activities that carry a high risk of fraud.

Based on the previous limitations, certain recommendations for further research can be singled out. One of them is the development of specific models for different areas (eg financial sector, public sector) which will include different factors and their different prioritization. It is also possible to create a model for risk assessment based on the Association of Certified Fraud Examiners reports on the presence of fraud in organizations. 


\section{References}

Balkaran, L. (2007). A solid reporting line. The Internal Auditor, 64(1), 96-97.

Beasley, M.S., Carcello, J.V., Hermanson, D.R. and Lapides, P.D. (2000). Fraudulent financial reporting: consideration of industry traits and corporate governance mechanisms. Accounting Horizons, 14 (4), 441-454.

Carcello, J. V., D. R. Hermanson and K. Raghunandan (2005). Factors associated with U.S. public companies' investment in internal auditing. Accounting Horizons, 19 (2), 69-84.

Carey, P., Craswell, A. and Simnett, R. (2000). Voluntary demand for internal and external auditing by family businesses. Auditing: A Journal of Practice \& Theory 19, 37-51.

Chadwick, W. E. (2000). Keeping internal auditing in-house. International Auditor. 57(3), p. 88 .

Coram, P., Ferguson, C. and Moroney, R. (2008). Internal audit, alternative audit structures and the level of misappropriation of assets fraud. Accounting and Finance, 48(4), 1-17.

Demski, J. S. (2003). Corporate conflicts of interest. Journal of Economic Perspectives, $17(2), 51-72$.

Goodwin, J. and Kent, P. (2004). Factors affecting the voluntary use of internal audit. Working Paper, Queensland University of Technology, 1-41.

The Institute of Internal Auditors (2011). International Standards for the Professional Practice of Internal Auditing -Međunarodni standardi za profesionalnu praksu interne revizije. Retrieved from URL:

https://global.theiia.org/translations/PublicDocuments/Standards_2011_Bosnian.pdf

(Accessed March 25, 2021.)

International Federation of Accountants (2009). International Standards on Auditing 240 The Auditor's Responsibility to Consider Fraud in the Audit of Financial Statements (ISA 240). Retrieved from URL: https://www.ifac.org/system/files/downloads/a012-2010-iaasbhandbook-isa-240.pdf (Accessed March 10, 2021.)

Kaplan, S. and Schultz, J. (2007). Intentions to report questionable acts: An examination of the influence of anonymous reporting channel, internal audit quality, and setting. Journal of Business Ethics, 71, 109-124.

Keitsh, D. (2000). Riskomanagement. Stuttgart: Schaffer-Poeschel.

King, R. (2002). An experimental investigation of self-serving biases in an auditing trust game: the effect of group affiliation. The Accounting Review, 77(2), 265-284.

Moeller, R. (2007). COSO Enterprise Risk Management - Understanding the New Integrated ERM Framework. New Jersey: John Wiley \& Sons.

Nestor, S. (2004). The impact of changing corporate governance norms on economic crime. Journal of Financial Crime, 11(4), 347-352. 
Osmanagić-Bedenik, N. (2003). Kriza kao šansa: kroz poslovnu krizu do poslovnog uspjeha. Zagreb: Školska knjiga.

Salierno, D. (2007). Managing change. The Internal Auditor, 64(1), 51-54.

Savez računovođa, revizora i finansijskih radnika FBiH (2017). MRevS 240 - Revizorove odgovornosti u vezi sa prevarama u reviziji finansijskih izvještaja. Retrieved from URL: http://www.srr-fbih.org/File/Download?idFi=645 (Accessed March 10, 2021.)

The IIA Research Foundation (2007). Risk Management: Proffesional Practices Framework. Altamonte Springs: The IIA Research Foundation.

Walker, P., Shenkir, W. And Barton, T. (2002). Enterprise Risk Management: Pulling in All Together. Altamonte Springs: The Institute of Internal Auditors Reseach Foundation.

Wallace, W. and Kreutzfeldt, R. (1991). Distinctive characteristics of entities with an internal audit department and the association of the quality of such departments with errors. Contemporary Accounting Research, 7(2), 485-512.

\section{Sažetak}

Svjedoci smo sve učestalije pojave nezakonitih radnji i prevara u poslovanju pravnih lica, što se direktno odražava na kvalitet informacija prezentiranih u finansijskim izmještajima. Interna revizija primarno se ne bavi revizijom finansijskih izvještaja, ali kroz provjeru primjene računovodstvenih politika i procedura pomaže u sticanju razumnog uvjerenja da su finansijski izvještaji pouzdani $i$ da su isti fer prezentirani. Uloga interne revizije u postupku otkrivanja prevara ogleda se kroz procjenu rizika prevara u postupku planiranja rada interne revizije, te kroz obavljanje radnih angažmana na otkrivanju istih. U radu ćemo prikazati tehnike procjene rizika, koje interni revizor može da primjeni kod kvantitativne i kvalitativne procjene rizika prevara, te kod utvrđivanja prioritetnih područja/procesa revidiranja. Cilj rada je ukazati na značajnost uloge interne revizije, kroz primjenu tehnika, alata i propisane odgovornosti procjene rizika, u postupku otkrivanja prevara u preduzećima koje svakodnevno donose nesagledive štete.

Ključne riječi: Interna revizija, Procjena rizika, Planiranje, Revidiranje, Otkrivanje prevara 